\title{
HUBUNGAN FREKUENSI PENIMBANGAN, PENGGUNAAN GARAM BERYODIUM, DAN PEMBERIAN VITAMIN A DENGAN KEJADIAN UNDERWEIGHT PADA BALITA DI PROVINSI JAWA TIMUR
}

\author{
Relationship between Weighing Frequency, Use of Iodized Salt, and Vitamin A Supplementation \\ with Underweight among Children Under Five in East Java
}

\author{
Nafijah Muliah ${ }^{1}$, Agus Sri Wardoyo ${ }^{2}$, Trias Mahmudiono ${ }^{3}$ \\ ${ }^{1}$ Program Studi S1 Kesehatan Masyarakat, Fakultas Kesehatan Masyarakat, Universitas Airlangga, Surabaya \\ ${ }^{2}$ Seksi Kesehatan Keluarga dan Gizi Masyarakat, Dinas Kesehatan Provinsi Jawa Timur \\ ${ }^{3}$ Departemen Gizi Kesehatan, Fakultas Kesehatan Masyarakat, Universitas Airlangga, Surabaya \\ Email: nafijahmuliah@gmail.com
}

\begin{abstract}
ABSTRAK
Penyebab masalah gizi sangat beragam, diantaranya yaitu kurangnya asupan makanan, penyakit yang diderita, pola asuh dan masih banyak penyebab lainnya. Salah satu masalah pola asuh yang sering terjadi ialah anak tidak ditimbang secara teratur. Yodium adalah salah satu zat gizi yang berhubungan dengan pertumbuhan anak, selain itu anak yang mengalami gizi buruk biasanya menderita kekurangan Vitamin A sebagai akibat asupan zat gizi mereka yang sangat kurang. Tujuan dari penelitian ini yaitu untuk mengetahui hubungan antara frekuensi penimbangan, penggunaan garam beryodium, dan pemberian Vitamin A dengan kejadian underweight pada balita di provinsi Jawa Timur. Penelitian ini merupakan analisis data sekunder yang berasal dari survey Pemantauan Status Gizi Provinsi Jawa Timur tahun 2016. Sampel dalam studi ini sebanyak 10.440 rumah tangga yang memiliki balita di Jawa Timur. Analisis statistik dilakukan secara univariat berupa distribusi frekuensi dan analisis bivariat berupa uji Chi-Square untuk mengetahui hubungan antar variabel dan regresi logistik untuk mengetahui odd ratio variabel bebas terhadap kejadian underweight. Sebanyak 18,5\% balita di Jawa Timur mengalami underweight, $2 \%$ mengalami gizi lebih, dan 79,5\% normal. Terdapat hubungan antara pemberian Vitamin A warna biru $(p<0,001 ; \mathrm{OR}=0,638 ; 95 \% \mathrm{CI}: 0,580-0,782)$ dengan kejadian underweight pada balita, namun tidak ditemukan hubungan frekuensi penimbangan $(\mathrm{p}=0,729)$ dan penggunaan garam beryodium $(\mathrm{p}=0,620)$ dengan kejadian underweight. Kesimpulan dari penelitian ini ialah pemberian Vitamin A warna biru berhubungan dengan kejadian underweight di Jawa Timur.
\end{abstract}

Kata kunci: frekuensi penimbangan, garam beryodium, underweight, vitamin A

\section{ABSTRACT}

The are many causes of nutritional problems, including lack of food intake, illness, caring pattern and many other causes, one of the problems that often happen is the children had not weighed regularly. Iodine is one of the nutrients associated with the growth of children. On the other hand, children who are suffering from malnutrition usually also has Vitamin A deficiency as a result of their lack of nutrient intake. The purpose of this study was to analyze the relationship between the frequency of weighting, the use of iodized salt, and Vitamin A supplementation with underweight among children under five in East Java Province. This study was secondary data analysis from Monitoring of Nutritional Status (MNS) in East Java, 2016. The sample of this study were 10.440 households with children under five. 18.5\% children under five in East Java were underweight, 2\% overweight, and 79.5\% were normal. Distribution of frequency were performed as univariate statistical analysis and the relationship between variables were analyzed by chi-square test. The odd ratio were analyze by logistic regression. There was significant correlation between blue-colored vitamin $A$ supplementation ( $p<0.001 ; O R=0.638 ; 95 \%$ CI:0.580-0.78w2) with underweight. However, there was no correlation between weighing frequency $(p=0,729)$ and the use of iodized salt $(p=0,620)$ with underweight. The conclusion of this study highlight that there was correlation between Vitamin A supplementation with underweight in East Java.

Keywords: weighing frequency, iodized salt, underweight, vitamin A 


\section{PENDAHULUAN}

Balita mengalami siklus pertumbuhan dan perkembangan yang membutuhkan zat gizi yang lebih besar dibanding dengan kelompok umur yang lain, sehingga balita lebih rentan mengalami masalah gizi (Notoatmojo, 2003). Penyebab kondisi tersebut antara lain karena pada saat fase balita terjadi pertumbuhan dan perkembangan yang sangat pesat, disamping itu balita juga biasanya memiliki gangguan nafsu makan, serta mendapat asupan zat gizi yang tidak sesuai kuantitas atau kualitasnya (Departemen Kesehatan Republik Indonesia, 2006).

Gizi kurang (underweight) dan gizi buruk dapat menyebabkan gangguan jasmani dan kesehatan pada balita (Yanti, 2015). Kejadian gizi buruk akan menyebabkan daya tahan tubuh anak menurun dan anak juga akan lebih mudah terkena penyakit infeksi. Gizi buruk yang terjadi pada anak apabila tidak ditangani dengan baik dan cepat karena dapat mempengaruhi kualitas generasi selanjutnya (Yanti, 2015).

Hasil Riset Kesehatan Dasar (Riskesdas) tahun 2013 menunjukkan bahwa prevalensi underweight (berat-kurang) secara nasional pada balita adalah sebesar $19,6 \%$ yang terdiri dari $5,7 \%$ persen gizi buruk dan $13,6 \%$ balita yang mengalami gizi kurang. Prevalensi tersebut meningkat jika dibandingkan dengan prevalensi underweight pada tahun 2007 yaitu sebesar 18,4\% dan pada tahun 2010 sebesar 17,9\% (Kemenkes RI, 2013). Prevalensi ini juga melebihi target millenium development goals (MDG's) sendiri pada tahun 2015 yaitu sebesar 15,5\% untuk underweight, sehingga perlu dilakukan upaya penurunan angka underweight untuk mencapai target tersebut (Kemenkes RI, 2013).

Penyebab masalah gizi yang terjadi pada anak sangat beragam, diantaranya yaitu kurangnya asupan, penyakit yang diderita, pola asuh dan masih banyak penyebab lainnya. Apabila terjadi ketidaksesuaian antara jumlah zat gizi yang masuk dengan kebutuhan tubuh maka akan mendorong balita mengalami masalah gizi (Marimbi, 2010).

Salah satu masalah pola asuh anak yang dapat menyebabkan kurang gizi adalah anak tidak ditimbang secara teratur. Hasil Riset Kesehatan Dasar tahun 2010 menunjukkan balita yang ditimbang $>4$ kali dalam 6 bulan sebanyak 44,6\%, angka tersebut sedikit menurun dibandingkan pada tahun 2007 yaitu sebesar 45,4\% (Kemenkes, 2013). Penimbangan balita biasanya dilakukan di Posyandu. Ibu yang jarang pergi ke posyandu kurang mendapatkan informasi tentang status gizi balita, ibu juga tidak mendapat dukungan dan dorongan dari petugas kesehatan untuk mengatasi permasalahan kesehatan balitanya dengan segera, manfaat lain jika ibu rutin datang ke posyandu adalah ibu dapat memantau pertumbuhan dan perkembangan balita yang tidak terpantau secara optimal (Maulana, 2013).

Anak yang mengalami Kurang Energi Protein (KEP) atau gizi buruk biasanya menderita kekurangan Vitamin A sebagai akibat asupan zat gizi yang kurang, termasuk salah satunya yaitu vitamin A. Penelitian yang dilakukan oleh Murage, et al. tahun 2008 di Kenya menunjukkan anak yang tidak diberi Vitamin A 75\% lebih berisiko menderita underweight dibanding yang diberikan Vitamin A (Murage, et al., 2012).

Penggunaan garam beryodium dapat mempengaruhi status gizi anak karena yodium merupakan salah satu zat gizi yang berperan dalam pertumbuhan anak (Mazarina, 2012). Penelitian yang dilakukan oleh Karolina, dkk. (2012) di Kabupaten Gayo Lues menunjukkan bahwa keluarga yang menggunakan garam beryodium sebagian besar $(78,2 \%)$ memiliki status gizi normal berdasarkan indikator $\mathrm{BB} / \mathrm{TB}$. Penelitian yang dilakukan Zahraini (2009) juga menyatakan bahwa terdapat hubungan antara penggunaan garam beryodium dengan status gizi dengan menggunakan indeks $\mathrm{BB} / \mathrm{TB}$. Penelitian ini bertujuan untuk mengetahui hubungan antara frekuensi penimbangan, penggunaan garam beryodium, dan pemberian Vitamin A dengan kejadian underweight pada balita di provinsi Jawa Timur.

\section{METODE}

Penelitian ini merupakan penelitian cross sectional dengan data sekunder yang berasal dari survey Pemantauan Status Gizi (PSG) di Jawa Timur tahun 2016. Sampel dalam penelitian ini merupakan rumah tangga yang mempunyai balita 
berusia 0-59 bulan di Jawa Timur. Survei PSG dilakukan pada bulan Juni 2016 sampai dengan Desember tahun 2016. Pemilihan klaster di kabupaten/kota dilakukan secara acak sistematik berdasarkan Probability Proportional to Size (PPS) dengan bantuan tabel random. Klaster yang diambil tiap kabupaten/kota ialah sejumlah 30 desa, jika kabupaten/kota tersebut terdiri kurang dari 30 desa maka diambil seluruh desa di kabupaten/kota tersebut. Setiap klaster diambil 10 rumah tangga untuk dijadikan sampel dalam survey penentuan status gizi (Kemenkes RI, 2015).

Penelitian ini diawali dengan pengumpulan data yang berasal dari survey pemantauan status gizi (PSG) yang berasal dari Dinas Kesehatan Provinsi Jawa Timur tahun 2016, kemudian dilakukan data cleaning untuk menghilangkan data yang tidak sesuai dan tidak bisa digunakan, setelah itu dilakukan analisis data dengan menggunakan software SPSS. Data yang digunakan meliputi data antropometri balita, frekuensi penimbangan balita selama 6 bulan terakhir, jenis garam yang digunakan rumah tangga, dan data pemberian Vitamin A selama 6 bulan terakhir.

Jumlah sampel dalam survey ini ialah 10.440 sampel, dimana sampel awal survey PSG adalah 12.049 data balita, setelah dilakukan data cleaning didapatkan 10.440 sampel yang memenuhi kriteria. Hal ini dikarenakan ketidaklengkapan data (tidak ada keterangan status gizi, tidak ada keterangan frekuensi penimbangan, penggunaan garam beryodium dan pemberian vitamin A warna biru sejak umur 6 bulan). Pengurangan jumlah sampel dapat menyebabkan terjadinya perbedaan prevalensi underweight serta distribusi variabel lainnya antara hasil survey PSG tahun 2016 dengan hasil penelitian ini.

Variabel bebas dalam penelitian ini ialah frekuensi penimbangan balita selama 6 bulan terakhir, penggunaan garam beryodium rumah tangga, dan pemberian Vitamin A selama 6 bulan terakhir. Sementara variabel terikat adalah kejadian underweight di Jawa Timur. Analisis data dilakukan secara deksriptif berupa distribusi frekuensi dan inferensial berupa chi-square test untuk mengetahui hubungan antara variabel bebas dengan kejadian underweight pada balita dan regresi logistik untuk mengetahui pengaruh serta nilai odd ratio masing-masing variabel terhadap kejadian underweight pada balita.

\section{HASIL DAN PEMBAHASAN}

Hasil penelitian ini menunjukkan bahwa $79,5 \%$ balita di Jawa Timur pada tahun 2016 memiliki status gizi normal, 18,5\% underweight (kurang+buruk) dan 2,0\% memiliki status gizi lebih (Gambar 1). Prevalensi underweight di Jawa Timur masih berada diatas target nasional pada tahun 2015 yaitu sebesar 15,5\% (Kemenkes, 2013). Hasil tersebut menunjukkan bahwa masih diperlukan upaya untuk menurunkan angka underweight pada balita di Jawa Timur agar dapat mencapai target yang telah ditentukan. Upaya penurunan masalah gizi utamanya pengurangan balita yang mengalami underweight bergantung pada banyak faktor, diantaranya yaitu dukungan sumber daya yang ada dan juga peningkatan kualitas manajemen baik teknis maupun operasional (Kalsum dan Jahari, 2015).

Balita yang memiliki status gizi yang baik cenderung memiliki status kesehatan yang baik juga. Hal tersebut dikarenakan terdapat hubungan antara status gizi dengan penyakit infeksi pada balita, malnutrisi yang terjadi pada balita dapat meningkatkan morbiditas dan kerentanan balita terhadap penyakit infeksi begitupun terjadi sebaliknya, apabila balita mengalami infeksi maka balita tersebut akan lebih rentan menderita masalah gizi (Rodriguez, et al., 2011).

Tabel 1 menunjukkan sebagian besar balita ditimbang $\geq 4$ kali dalam 6 bulan terakhir $(88,3 \%)$, rumah tangga mengonsumsi garam beryodium

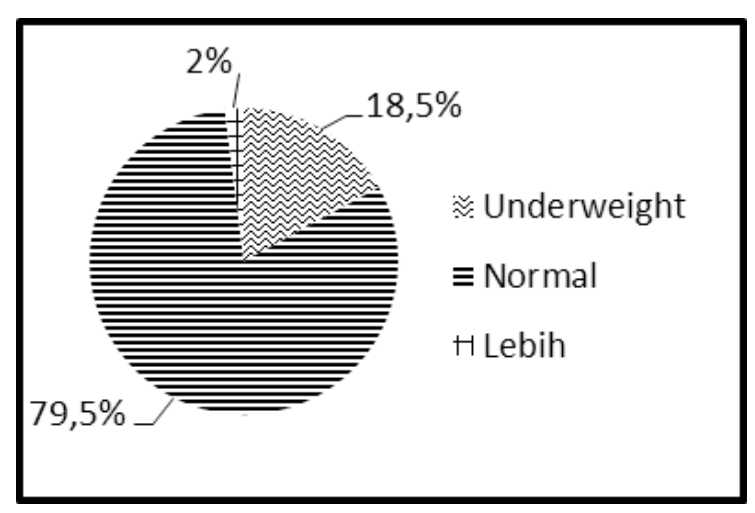

Gambar 1. Distribusi Frekuensi Status Gizi Balita 
Tabel 1. Distribusi Frekuensi Penimbangan, Penggunaan Garam Beryodium, dan Pemberian Vitamin A pada Balita

\begin{tabular}{lcc}
\hline \multicolumn{1}{c}{ Variabel } & n & $\mathbf{\%}$ \\
\hline Berapa kali ditimbang selama 6 bulan terakhir & & \\
$\quad \geq 4$ kali & 9221 & $88,3 \%$ \\
$\quad<4$ Kali & 1219 & $11,7 \%$ \\
Garam yang digunakan rumah tangga & & $79,8 \%$ \\
$\quad$ Beryodium & 8332 & $20,2 \%$ \\
$\quad$ Tidak Beryodium & 2108 & \\
Pemberian Vitamin A biru sejak umur 6 bulan & & $91,7 \%$ \\
Ya & 9572 & $8,3 \%$ \\
$\quad$ Tidak/belum pernah & 868 & \\
\hline
\end{tabular}

Tabel 2. Hasil Uji Korelasi Frekuensi Penimbangan, Penggunaan Garam Beryodium, dan Pemberian Vitamin A dengan Kejadian Underweight pada Balita

\begin{tabular}{|c|c|c|c|c|c|c|c|}
\hline \multirow{3}{*}{ Variabel } & \multicolumn{4}{|c|}{ Status Gizi Balita } & \multirow{3}{*}{$\mathbf{p}$} & \multirow{3}{*}{$\begin{array}{c}\text { Odd } \\
\text { Ratio }\end{array}$} & \multirow{3}{*}{$95 \% \mathrm{CI}$} \\
\hline & \multicolumn{2}{|c|}{ Gizi normal dan lebih } & \multicolumn{2}{|c|}{ Underweight } & & & \\
\hline & $\mathbf{n}$ & $\%$ & $\mathbf{n}$ & $\%$ & & & \\
\hline \multicolumn{8}{|c|}{$\begin{array}{l}\text { Berapa kali ditimbang } \\
\text { selama } 6 \text { bulan terakhir }\end{array}$} \\
\hline$\geq 4$ kali & 7519 & $88,4 \%$ & 1702 & $88,1 \%$ & \multirow{2}{*}{0,729} & \multirow{2}{*}{1,027} & \multirow{2}{*}{$0,882-1,197$} \\
\hline$<4$ kali & 989 & $11,6 \%$ & 230 & $11,9 \%$ & & & \\
\hline \multicolumn{8}{|l|}{$\begin{array}{l}\text { Garam yang digunakan } \\
\text { rumah tangga }\end{array}$} \\
\hline Beryodium & 6798 & $79,9 \%$ & 1534 & $79,4 \%$ & \multirow{2}{*}{0,620} & \multirow{2}{*}{1,031} & \multirow{2}{*}{$0,913-1,166$} \\
\hline Tidak Beryodium & 1710 & $20,1 \%$ & 398 & 20,6 & & & \\
\hline \multicolumn{8}{|c|}{$\begin{array}{l}\text { Pemberian Vitamin A } \\
\text { biru sejak umur } 6 \text { bulan }\end{array}$} \\
\hline $\mathrm{Ya}$ & 7753 & $91,1 \%$ & 1819 & $94,1 \%$ & \multirow{2}{*}{0,000} & \multirow{2}{*}{0,638} & \multirow{2}{*}{$0,520-0,782$} \\
\hline Tidak/belum pernah & 755 & $8,9 \%$ & 113 & $5,9 \%$ & & & \\
\hline
\end{tabular}

(79,8\%) dan anak diberi vitamin A biru sejak berumur 6 bulan $(91,7 \%)$.

\section{Hubungan Frekuensi Penimbangan dengan Kejadian Underweight pada Balita}

Hasil uji menunjukkan tidak terdapat hubungan antara frekuensi penimbangan balita selama 6 bulan terakhir dengan kejadian underweight $(\mathrm{p}=0,729)$. Hasil uji ini sesuai dengan penelitian yang dilakukan Nurhayati, et al (2004) yang menyatakan tidak terdapat hubungan antara frekuensi partisipasi penimbangan dengan status gizi pada anak. Hasil dari uji tersebut tidak sesuai dengan penelitian yang dilakukan Octaviani, et al. (2009), bahwa ada hubungan yang signifikan antara keaktifan dalam kegiatan posyandu dengan status gizi pada balita. Keluarga yang tidak aktif mengikuti kegiatan posyandu berisiko 6,857 kali mengalami kurang energi protein dibanding dengan keluarga yang aktif mengikuti kegiatan posyandu.
Kegiatan penimbangan biasanya dilakukan saat kegiatan posyandu rutin tiap bulan. Menurut Maulana (2013) ibu yang aktif ke posyandu dapat mencegah terjadinya peningkatan jumlah balita BGM melalui upaya mendeteksi secara dini status gizi balita setiap bulannya oleh petugas kesehatan bersama kader posyandu dalam memantau status gizi anak melalui penimbangan dan buku Kartu Menuju Sehat (KMS) balita.

Penimbangan balita yang dilakukan rutin di posyandu yang disertai dengan konseling dan pemberian makanan tambahan pada balita setiap bulannya dapat menurunkan angka kejadian gizi buruk dikarenakan status gizi anak yang ada pada KMS dapat selalu dipantau dan apabila ada permasalahan dapat langsung terselesaikan (Octaviani, et al., 2009). Tidak adanya hubungan antara frekuensi penimbangan balita dengan underweight di Jawa Timur dapat disebabkan karena masyarakat yang hadir ke posyandu hanya 
untuk melakukan penimbangan namun fungsi konseling yang dilakukan di posyandu belum maksimal, sehingga tidak berpengaruh terhadap status gizi anak (Rarastiti, 2013).

\section{Hubungan Penggunaan Garam Beryodium dengan Kejadian Underweight pada Balita}

Hasil uji menunjukkan tidak ada hubungan antara penggunaan garam beryodium pada keluarga dengan kejadian underweight pada balita $(p=0,620)$. Hasil ini tidak sejalan dengan penelitian yang dilakukan oleh Zahraini (2009) yang menyatakan bahwa ada hubungan antara penggunaan garam beryodium dengan status gizi buruk menurut indeks BB/U. Dari hasil penelitian tersebut menunjukkan bahwa seluruh balita yang berasal dari rumah tangga yang menggunakan garam beryodium persentase terbesar terlihat pada balita dengan status gizi normal menurut indeks IMT/U yaitu sebesar $86,5 \%$, sedangkan pada balita yang berasal dari rumah tangga yang tidak menggunakan garam beryodium persentase terbesar pada balita yang mempunyai status gizi pendek sebesar 53\% (Zahraini, 2009).

Penggunaan garam beryodium selama ini lebih sering dikaitkan dengan kejadian stunting. Berdasarkan hasil penelitian yang dilakukan Devi (2012) menunjukkan bahwa penggunaan garam beryodium dapat mempengaruhi status gizi anak (TB/U) karena yodium adalah salah satu zat gizi yang mempunyai peran dalam pertumbuhan. Senyawa T3 adalah senyawa yang berfungsi untuk mengontrol laju metabolisme basal sel. Yodium sangat diperlukan untuk membantu produksi senyawa T3 pada tubuh. Apabila kadar senyawa T3 pada tubuh mengalami kekurangan akibat kebutuhan yodium yang tidak terpenuhi, maka laju metabolisme basal sel juga akan menjadi rendah, hal tersebut dapat mengakibatkan proses tumbuh kembang yang terjadi di dalam tubuh manusia menjadi terganggu dan terhambat.

Anak yang mengalami kekurangan yodium bisa juga mengalami retardasi pertumbuhan sehingga anak tersebut kerdil, hal tersebut terjadi karena pada anak yang kekurangan yodium akan terjadi penurunan laju metabolisme, retensi nitrogen rendah, dan beberapa fungsi beberapa sistem organ akan lebih rendah. Selain itu, hal tersebut juga dapat menyebabkan jaringan tulang tidak matang karena maturasi epifase terlambat sehingga pertumbuhan tulang panjang pun akan terhambat (Dyah, dkk., 2010).

\section{Hubungan Pemberian Vitamin A Warna Biru Sejak Umur 6 Bulan dengan Kejadian Underweight pada Balita}

Hasil uji statistik menunjukkan bahwa terdapat hubungan antara pemberian vitamin A dengan kejadian underweight yang ditunjukkan dengan nilai $\mathrm{OR}=0,638(p=0,000 ; 95 \% \mathrm{CI}: 0,520-0,782)$ hasil tersebut menunjukkan bahwa balita yang mendapatkan Vitamin A warna biru sejak umur 6 bulan memiliki peluang sebesar 37\% untuk terhindar dari risiko underweight daripada balita yang tidak mendapatkan Vitamin A warna biru sejak umur 6 bulan.

Hasil uji ini sejalan dengan penelitian yang dilakukan di India menunjukkan bahwa anak yang asupan vitamin A nya tidak adekuat memiliki prevalensi stunting, underweight, dan wasting yang lebih tinggi dibanding anak yang memperoleh vitamin A secara adekuat. Defisiensi vitamin A dapat meningkatkan risiko mortalitas, morbiditas, dan penyakit infeksi yang lebih tinggi pada anak (Semba, dkk., 2010). Kurangnya asupan vitamin A dapat dikaitkan dengan terhambatnya pertumbuhan dikarenakan kurangnya vitamin A dapat mengurangi sekresi terhadap serum IGF-1 yang bertanggung jawab untuk sekresi hormon pertumbuhan (Mikhail, dkk., 2013).

Status vitamin A anak dipengaruhi oleh beberapa faktor, tidak hanya dari asupan vitamin A. Faktor lain yang memengaruhi status vitamin A diantaranya adalah cadangan vitamin A didalam tubuh yang disimpang di hati (Almatsier, et al., 2011).

Hasil penelitian ini tidak sejalan dengan penelitian yang dilakukan Karolina, dkk. (2012) yang menunjukkan bahwa tidak ada hubungan yang bermakna antara pemberian kapsul vitamin A kepada balita dengan status gizi berdasarkan indikator BB/U, TB/U dan BB/TB. Suplementasi Vitamin A diberikan kepada seluruh anak balita umur 6-59 bulan secara serentak. Untuk bayi umur 
6-11 bulan diberikan vitamin A kapsul biru (dosis 100.000 SI) pada bulan Februari dan Agustus (Depkes, 2009).

Alasan keluarga yang tidak/belum membawa balitanya saat pemberian kapsul vitamin A secara serentak dikarenakan keluarga tidak mengetahui jadwal pemberian kapsul vitamin A. Hal tersebut terjadi karena balita jarang dibawa ke posyandu sehingga akhirnya keluarga tidak memperoleh informasi jadwal pemberian kapsul vitamin A. Selain itu hal tersebut juga dikarenakan keluarga belum mengetahui tentang pentingnya manfaat vitamin A pada anak (Harahap, dkk., 2014).

\section{KESIMPULAN DAN SARAN}

Pemberian Vitamin A warna biru sejak umur 6 bulan dapat mencegah terjadinya underweight pada balita. Balita yang diberi Vitamin A warna biru sejak umur 6 bulan memiliki peluang 37\% lebih rendah untuk terhindar dari underweight dibanding balita yang tidak diberi Vitamin A warna biru.

Untuk mencegah terjadinya underweight pada balita diperlukan upaya untuk mempertahankan dan meningkatkan cakupan pemberian Vitamin A utamanya pada saat pemberian Vitamin A serentak pada bulan Februari dan Agustus.

\section{DAFTAR PUSTAKA}

Almatsier S, Soetardjo S, \& Soekatri M. (2011). Gizi seimbang dalam daur kehidupan. Jakarta, Indonesia: Gramedia Pustaka Utama.

Departemen Kesehatan Republik Indonesia. (2006). Pedoman umum pengelolaan posyandu. Jakarta, Indonesia: Departemen Kesehatan Republik Indonesia.

Devi, M. (2012). Hubungan penggunaan garam beryodium dengan pertumbuhan linier anak. Jurnal TIBBS (Teknologi Industri Boga dan Busana), 3(1), 52-57. Diakses dari http://download.portalgaruda.org/article. php? article $=98737 \&$ val $=420$.

Departemen Kesehatan Republik Indonesia. (2009). Panduan manajemen suplementasi Vitamin A. Jakarta, Indonesia: Direktorat Gizi Departemen Kesehatan RI.

Dyah, K., Hastin, \& Ina, K. (2010). Status gizi dan status iodium pada balita dengan suspect down syndrom. Media Gizi mikto Indonesia, 1(20), 46-
53. Diakses dari http://ejournal.litbang.depkes. go.id/index.php/mgmi/article/view/1171/718

Harahap, R., Lubis, Z., \& Ardiani, F. (2014). Gambaran perilaku sadar gizi pada keluarga yang memiliki balita gizi kurang dan gizi buruk yang ada di wilayah kerja Puskesmas Desa Lalang tahun 2014. Diakses dari http://download.portalgaruda.org/article.ph $\mathrm{p}$ ? article $=299205 \& \mathrm{val}=4108 \&$ title $=\mathrm{GAM}$ BARAN\%20PERILAKU\%20SADAR $\% 20$ GIZI\%20PAD A \%20KELUARGA\%20 YANG\%20MEMILIKI\%20BALITA\%20 GIZI\%20KURANG\%20DAN\%20GIZI\%20B UR U K \% 20 D I \% 20 W IL A YA H \% 20 KERJA\%20PUSKESMAS\%20DESA \%20 LALANG

Kalsum, U., \& Jahari, A.B. (2015). Strategi menurunkan prevalensi gizi kurang pada balita di Provinsi Jambi. Jambi Medical Journal, 3 (1), 45-59. Diakses dari https://online-journal.unja. ac.id/index.php/kedokteran/article/view/2719

Kementerian Kesehatan Republik Indonesia. (2013). Riset dasar kesehatan tahun 2013. Jakarta, Indonesia: Badan Penelitian dan Pengembangan Kementerian Kesehatan Republik Indonesia.

Kementrian Kesehatan Republik Indonesia. (2015). Pedoman teknis pemantauan status gizi. Jakarta, Indonesia: Direktorat Jenderal Bina Gizi dan KIA Kementrian Kesehatan RI.

Karolina, E., Nasution, E., Aritonang E.Y. (2012). Hubungan perilaku KADARZI dengan status balita usia 12-59 bulan di wilayah kerja Puskesmas Blangkejeren Kecamatan Blagkejeren Kabupaten Gayo Lues tahun 2012. Diakses dari https://jurnal.usu.ac.id/index.php/ gkre/article/viewFile/2089/1720

Marimbi, H. (2010). Tumbuh kembang, status gizi, dan imunisasi dasar pada balita. Yogyakarta, Indonesia: Nuha Medika.

Maulana, A. (2013). Hubungan keaktifan ibu dalam posyandu dengan penurunan jumlah balita bawah garis merah (bgm) di Desa Suko Jember Kecamatan Jelbuk Kabupaten Jember (Skripsi tidak dipublikasikan). Fakultas Kesehatan Masyarakat Universitas Negeri Jember, Jember.

Mazarina, D. (2012). Hubungan penggunaan garam beryodium dengan pertumbuhan linier anak. Teknologi Industri Boga dan Busana), 3(1), 52-57.

Mikhail, W.Z.A., Sobhy, H.M., El-Sayed, H.H., Khairy, S.A., Abu Salem, H.Y.H., \& Samy, M.A. 
(2013). Effect of nutritional status on growth pattern of stunted preschool children in Egypt. Academic Journal of Nutrition, 2(1), 01-09. DOI: 10.5829/idosi.ajn.2013.2.1.7466

Murage, E.W., Crispin, N., Katherine R., \& Peninah, M. (2012). Vitamin A supplementation and stunting levels among two year olds in Kenya: Evidence from the 2008-09 Kenya demographic and health survey. International Journal of Child Health and Nutrition, 1, 135-147.

Notoatmodjo S. (2003). Prinsip-prinsip dasar ilmu kesehatan masyarakat. Jakarta, Indonesia: Rineka Cipta.

Nurhayati, I., Hakimi, M., \& Hartini, S.N., (2004). Hubungan kesadaran gizi keluarga dengan status gizi anak bawah dua tahun (Baduta) di Kabupaten Purworejo. Jurnal Penelitian Gizi dan Makanan, 27 (2), 25-33. Diakses dari http:// ejournal.litbang.depkes.go.id/index.php/pgm/ article/view/1413

Octaviani, U., Juniarti, N., \& Mardiyah, A. (2009). Hubungan keaktifan keluarga dalam kegiatan posyandu dengan status gizi balita di Desa Rancaekek Kulon Kecamatan Rancaekek. Diakses pada repository.unpad.ac.id/3625/1/ hubungan_keaktifan_keluarga.pdf

Rarastiti, C.N. (2013). Hubungan karakteristik ibu, frekuensi kehadiran anak ke posyandu, asupan energi dan protein dengan status gizi anak usia 1-2 tahun (Skripsi). Universitas Dipenegoro, Semarang.

Rodríguez, L., Cervantes, E., \& Ortiz, R. (2011). Malnutrition and gastrointestinal and respiratory infections in children: A public health problem. International Journal of Environmental Research and Public Health. 8 (4), 1174-1205. doi: 10.3390/ijerph8041174

Semba, R.D. Pee, S., Sun, K. Campbell, A.A., Bloem, M.W., \& Raju, V.K. (2010). Low intake of vitamin A-rich foods among children, aged 12-35 months, in India: Association with malnutrition, anemia, and missed child survival interventions. Nutrition, 26(10), 958-962. doi: 10.1016/j.nut.2009.08.010.

Yanti, K.D. (2015). Faktor - faktor yang berhubungan dengan status gizi buruk pada balita di Desa Kute Kecamatan Pujut Kabupaten Lombok Tengah Nusa Tenggara Barat . Diakses dari http://ejournalnwu.ac.id/article/ view/1443664651

Zahraini, Y. (2009). Hubungan status KADARZI dengan status gizi balita usia 12 - 59 bulan di Provinsi DI Yogyakarta Dan Nusa Tanggara Timur Tahun 2009 (Skripsi tidak diterbitkan). Fakultas Kesehatan Masyarakat Universitas Indonesia, Jakarta. 